\title{
A Multi-Task Theory of the State Enterprise Reform
}

By: Chong-En Bai, David D. Li, Zhigang Tao, and Yijiang Wang

Working Paper No. 367

March 2001 


\section{A M ulti-Task Theory of the State Enterprise R eform ${ }^{1}$}

Chong-En Bai

The University of Hong Kong, Hong Kong and WDI

David D. Li

Hong Kong University of Science and Technology, Hong Kong, CEPR and WDI

Zhigang Tao

The University of Hong Kong, Hong Kong

Yijiang Wang

University of Minnesota, Minneapolis, MN 55455, CEPR and WDI

Suggested running head: Multi-Task and State Enterprises

Correspondence to: Chong-En Bai, School of Economics and Finance, The University of Hong Kong, Pokfulam, Hong Kong. Tel: (852) 2859-1036. E-mail: baic@hku.hk. 


\section{A bstract}

During transition, maintaining employment and providing a social safety net to the unemployed are important to social stability, which in turn is crucial for the productivity of the whole economy. Because independent institutions for social safety are lacking and firms with strong profit incentives have little incentives to promote social stability due to its public good nature, state-owned enterprises (SOEs) are needed to continue their role in providing social welfare. Charged with the multi-tasks of efficient production as well as social welfare provision, SOEs continue to be given low profit incentives and consequently, their financial performance continues to be poor.

K eywords: Dual-track reform, multi-task, social stability, unemployment

J ournal of Economic Literature Classification Numbers: P31, P23, P20, D21, J23, L20 


\section{Acknowledgement:}

This is a revised version of our earlier working paper titled "State Enterprises in Transition: A Multi-Task Perspective." We thank John Bonin, participants of the William Davidson Institute's 1997 Workshop and 1997 AEA Meetings for their many helpful comments. We would also like to thank Roger Gordon, Yingyi Qian, Gerard Roland, Jan Svejnar, and Chenggang Xu for earlier discussions on the topic. Partial financial supports from the URC research grant of HKU (Chong-En Bai), DAG99/00/BM24 and the Chinese SOE project of the HLCOR of the HKUST (David Li), the Research Grants Council of Hong Kong (Zhigang Tao), and the Graduate School's Grant-in-Aid, University of Minnesota (Yijiang Wang) are gratefully acknowledged.

\section{Non-Technical Summary:}

This paper explains why in almost all transition economies, reforms of State-Owned Enterprises (SOEs) have been slow and SOEs continue to have poor financial performance. We start with the observation that, during transition, a social safety net has to be established in order to achieve social stability. Otherwise, social instability caused by mass unemployment would create an undesirable general environment for business and thereby lower the overall efficiency in the economy. However, at the start of reform, independent agencies specializing in providing a social safety net are missing because, before transition, SOEs functioned as the main social welfare providers. It is very difficult to establish quickly an institution independent of the SOEs to provide the safety net even if the funding is available. Therefore, during transition, the government chooses to slow down the SOE reform and to keep a certain number of SOEs in order to maintain social stability. The remaining SOEs continue to be charged with multiple tasks, i.e., the task of production and that of social welfare provision.

More specifically, the paper has the following predictions. First, if the existing level of social stability is low, the reformist government should maintain a certain proportion of SOEs during transition, i.e., a complete privatization of SOEs should be delayed. The rationale is that, by delaying privatization, the multi-tasked SOEs continue to face low profit incentives and, therefore, have little incentive to divert unobservable effort from social welfare provision to production. Meanwhile, with profit as their sole objective, private firms have little incentives to spend resources on social stability due to its public good nature. Second, as a result of multi-tasking, SOEs' financial performance is inevitably poor during reform. In particular, the profitability of an SOE is lower than that of a private firm. This is not only because SOEs have to spend resources on maintaining social stability but also because they are given low profit incentives by the government. Third, when the existing level of social stability is higher or the total factor productivity of an SOE is low relative to that of a private firm, the reformist government should reduce the proportion of SOEs, i.e., the process of privatization should speed up. 
The paper extends the general analysis to two important cases. The first is a reformist government at the beginning of transition that can directly enhance social stability at a cost, e.g., by using tax revenue collected with a social cost. We show that, when the cost is very high, the government chooses not to spend sufficient resources itself on social stability. As a result, SOEs are relied upon to provide needed social stability in transition. Conversely, when the cost is very low, the government chooses to spend sufficient resource itself on social stability so that SOEs are not relied upon to maintain stability. Hence, they are reformed at the beginning of the transition. The other extension is a consideration of unemployment in the labor market as a source of social instability. All the main results carry over to the extended models.

After presenting a theory to illustrate the above argument, the paper discusses China's experience of SOE reform. We argue that the in the Chinese case, indeed social stability is a major concern of the reformist government. Because of this concern, the pace of SOE reform has been slow and SOEs have not been given profit incentives similar to those faced by private firms. As a result, profitability of Chinese SOEs has been decreasing. Yet, SOEs are forced not to lay off all the workers as they tend to.

There are two policy implications of the paper. First, A major objective of economic reform should be to establish an independent social safety net, since this is a foundation of other reforms. Second, before an independent social safety net is set up, it is better to slow down the reform of SOEs so as to induce SOEs to function as organizations of social stability provision. Although the performance of SOEs may suffer in the process, such a strategy improves the overall performance of the economy. 


\section{Introduction}

This paper presents a theory to explain why in almost all transition economies, reforms of State-Owned Enterprises (SOEs) have been slow and SOEs continue to have poor financial performance. The theory starts with the observation that, during transition, a social safety net has to be established in order to achieve social stability. Otherwise, social instability caused by mass unemployment would create an undesirable general environment for business and thereby lower the overall efficiency in the economy. However, at the start of reform, independent agencies specializing in providing a social safety net are missing because, before transition, SOEs functioned as the main social welfare providers. It is very difficult to establish quickly an institution independent of the SOEs to provide the safety net even if the funding is available. Therefore, during transition, the government chooses to slow down the SOE reform and to keep a certain number of SOEs in order to maintain social stability. The remaining SOEs continue to be charged with multiple tasks, i.e., the task of production and that of social welfare provision.

In Section 2, we use a stylized model to illustrate this theory. There are three groups of results. First, if the existing level of social stability is low, the reformist government should maintain a certain proportion of SOEs during transition, i.e., a complete privatization of SOEs should be delayed. The rationale is that, by delaying privatization, the multi-tasked SOEs continue to face low profit incentives and, therefore, have little incentive to divert unobservable effort from social welfare provision to production. Meanwhile, with profit as their sole objective, private firms have little incentives to spend resources on social stability due to its public good nature. Second, as a result of multi-tasking, SOEs' financial performance is inevitably poor during reform. In particular, the profitability of an SOE is lower than that of a private firm. This is not only because SOEs have to spend resources on maintaining social stability but also because they are given low profit incentives by the government. Third, when the existing level of social stability is higher or the total factor productivity of an SOE is low relative to 
that of a private firm, the reformist government should reduce the proportion of SOEs, i.e., the process of privatization should speed up.

After illustrating the key insights with a stylized model, we extend our analysis to two important cases. The first is a reformist government at the beginning of transition that can directly enhance social stability at a cost, e.g., by using tax revenue collected with a social cost. We show that, when the cost is very high, the government chooses not to spend sufficient resources itself on social stability. As a result, SOEs are relied upon to provide needed social stability in transition. Conversely, when the cost is very low, the government chooses to spend sufficient resource itself on social stability so that SOEs are not relied upon to maintain stability. Hence, they are reformed at the beginning of the transition. The other extension is a consideration of unemployment in the labor market as a source of social instability. All the main results carry over to the extended models. ${ }^{2}$

After the theory sections, empirical evidence from China's reform experience is presented in Section 5. We argue that the basic premise and predictions of the theory are supported by evidence from the experience of China's state enterprise reform. Although we feel that the theory is also relevant to other transition economies, future empirical work is needed to confirm this conjecture.

Our theory of SOE reform is based on a second-best argument. The conclusion that a certain proportion of SOEs should continue to exist during reform is driven by the condition that the government cannot find other means to provide a social safety net for unemployed workers. The first best solution is achievable if an independent social security system can be established so that this task can be separated from the SOEs. Then the government can provide strong profit incentives for SOEs, including possibly outright privatization and, thereby, improve their performance. The key reason for this last result is that the poor financial performance of the SOEs is not simply a reflection of the direct financial resources that the SOEs spend for social security and welfare purposes. In other words, it is not simply a result of the redistribution of economic 
benefits produced by SOEs. Instead, it reflects also the lower overall efficiency in SOEs due to weak profit incentives applied to induce them to carry out the multiple tasks. However, given that an independent institution to provide the public good does not exist and can not be established quickly, the second best social optimum is to keep a fraction of the firms in the economy state-owned and charge them with the task of producing the public good.

Our theory is not simply one of government intervention to deal with an externality. Although the externality is a critical element in our theory, at the center of our work are the questions of how private incentives affect the private supply of a public good and how the government should design incentives to achieve the best balance between private profit incentives and the private supply of public goods. ${ }^{3}$ To answer these questions, we derive our results on the optimal speed of privatization.

Several important observations are critical for our theory. The first is based on how social stability is maintained in transition. Unlike most mature market economies, there are no independent establishments specializing in providing social services and social safety net in a transition economy. Moreover, in the short run, it is very difficult and costly, if not impossible, for the government to establish such institutions. Existing bureaucracies, e.g., ministries of labor, finance, and civil welfare, may compete to obtain control rights of the new institution. Also, due to the stretched political capacity of the reformist government, monitoring such new institutions is difficult. Therefore, SOEs should continue to play the role of providing such services. A typical SOE in transition economies was established as a mini-community with all social service facilities, such as canteen, medical clinic, beauty saloon, theatre, and shuttle buses. It is very costly for the government to use tax revenue to replace such functions of SOEs. ${ }^{4}$ Our observation is that SOEs represent the dominant channel through which social services and the social safety net are provided in transition.

The second observation is that the efforts of SOE managers to provide social services and to maintain social stability are not observable. Although the government can 
instruct an SOE to keep a certain number of workers on its payroll, which indeed has been the case in reality, it cannot observe directly how well an SOE provides social services to its employees. Therefore, SOE managers must not face high-powered profit incentives that induce them to cut costs by not treating surplus workers properly. Similarly, a tax on SOEs for laying-off workers, the so-called unemployment tax, cannot induce SOE managers to provide social services, since this can at most prevent the SOE from laying-off workers. In China, a well known tendency is that SOEs treat surplus or unproductive workers as second class citizens by depriving them of many benefits, e.g., denying them health care benefits and delaying the repair work for the broken windows of their company-provided apartment. This tendency threatens to stir popular resentment against reform. Based on this observation, our assumption is that an SOE manager can escape government monitoring and divert efforts from providing social services to employees to seeking higher profits. This is the basis of our multi-task theory.

The third important observation is that obstacles exist in the labor market preventing it from clearing during transition. Should the labor market clear, the social welfare problem on which this paper is based would not exist. Then all SOEs can be made singletask agents. The government's concern for income distribution and its wage regulation to address this concern are a plausible reason for labor market imperfection in a transitional economy (see Gordon and Li, 1999).

Our analysis of the social safety net departs from those in the traditional literature that emphasize the trade-off between incentives and insurance for those covered by a social safety net. ${ }^{5}$ A social safety net provides insurance to economic agents but takes away their work incentives at the same time. This concern relates to the principal-agent relationship between workers and employers. Although the trade-off is an important issue, there is another issue that is unique in a transition economy and more urgent. This issue involves the principal-agent relationship between the state and the SOE managers and how to provide incentives for SOE managers to continue those social services that were traditionally supported by SOEs if independent institutions providing a social safety 
net cannot be established quickly enough. Since social stability is a public good, the efficiency of the whole economy is affected. This issue becomes critical to strategies of SOE reform. In this paper, we focus on the public goods nature of the safety net and show that this factor slows down SOE reform. ${ }^{6}$

Our paper is embedded in a lively literature on strategies of economic transition. ${ }^{7}$ Taking a political economy perspective, Dewatripont and Roland (1992a and 1992b) argue that, when the reformer has to compensate the losers of reform, a gradualist reform is likely to be optimal because it can isolate the losers at each stage and minimize government expenditure. Murrell and Wang (1993) discuss how institutional resource and structural legacies of a communist economy may lead to a delay in the privatization process. Qian and Xu (1993) provide insights into the effect of an economy's pre-reform organizational structure on the path of reform. Most closely related to our work are Castanheira and Roland (1996 and 2000), Qian (1996), Li (1997), and Roland and Verdier (1999). In a dynamic neoclassical Ramsey model of investment, Castanheira and Roland (1996 and 2000) show that too fast closure of SOEs reduces income and savings so that less investment can be made in non-SOEs. To explain the slow pace of SOE reforms, Qian (1996) and Li (1997) argue that the lack of large investors or institutions for corporate governance require continued government control of SOEs in order to curb the agency costs associated with excessive insider control. Finally, Roland and Verdier (1999) argue that high unemployment leads to congestion in the labor market and excessive search costs for new jobs.

Our paper adds to these existing works by providing a new dimension to the relationship between SOEs and non-SOEs, i.e., the issue of social stability. We show that SOE managers should be given low-powered incentives. Theoretically, our model builds upon Holmstrom and Milgrom's $(1991,1994)$ multi-task theory. Our innovation lies in emphasizing the difference in the scope of influence of the tasks. We introduce into the multi-task model the possibility that one of the tasks has a public good nature. As a result, we prove that it is optimal for the government to maintain a mix of SOEs and 
private enterprises, even if these enterprises are assumed to have identical production function and are managed by ex ante homogeneous agents.

\section{Theoretical Analysis}

In this section, we set up a highly stylized model to illustrate the main arguments of the paper. In the model, a reformist government decides on the pace of SOE reform by choosing a certain proportion of SOEs not to be reformed during the period. There are three main predictions of this model. First, if the initial level of social stability is low, the government chooses to keep some SOEs; these are given low profit incentives and instructed to devote efforts to maintaining social stability. Second, as a result, these SOEs are less profitable than private firms. Third, when either the initial level of social stability is higher or the total factor productivity of SOEs is lower, the government should choose to keep fewer SOEs, i.e., the government should speed up reform.

To illustrate the key insights, the stylized model assumes a fixed product price and does not explicitly consider the labor market. However, the main results remain unchanged quantitatively when these assumptions are dropped. ${ }^{8}$ As an illustration, in Section 4, we include the labor market by considering employment as a proxy for social stability. The extension of the basic model to include the product market competition can be found in an earlier version of the paper (Bai, Li, Tao and Wang, 1999). ${ }^{9}$

\subsection{The Model}

Suppose that there are infinite number of firms in the economy, populated in the unit interval $I=[0,1]$. The firms are of the following two types: private firms, the owner-managers of which keep all the profit, and state-owned enterprises (SOEs), the managers of which are paid fixed wages. We use $j$ to denote a private firm and $i$ to denote an SOE. The proportion of SOEs is $p \in[0,1]$.

The manager of each firm performs two tasks: $s$ and $g$. Task $s$ is a specific effort that affects only the revenue of the firm, and $g$ is a general effort that increases the revenue 
of all firms of the economy. Here $s$ and $g$ are called production effort and stability maintenance effort, respectively. The total cost of the efforts is born by the manager and given by:

$$
c=s+g \text {. }
$$

We assume that the levels of the two efforts are not verifiable and hence can not be the basis of a contract. However, through direct monitoring of managerial effort, the government can ensure a level of total effort of at least $T$ from each manager. Given the incentive contracts, the managers choose $s$ and $g$ according to their self-interest and subject to the constraint that:

$$
s+g \geq T \text {. }
$$

We assume that the level of social stability $G$ in the economy is given by:

$$
G={ }_{I}^{\mathrm{Z}} g(k) d k+G_{0},
$$

where the first term is the integral of the function $g$ over the interval $I$, or the aggregate of the stability maintenance efforts of all enterprises, and $G_{0}$ is the initial level of stability plus the government's effort in providing social stability. We assume that $G_{0}>0$. In our main case, we also assume that $G_{0}$ is largely determined by history and cannot be changed in the short term.

The revenue of each firm is assumed to be:

$$
x(k)=\lambda(k) y[s(k), G]+\epsilon(k),
$$

where $s(k)$ is firm $k$ 's specific effort, $\epsilon(k)$ is a random variable with mean 0 and variance $\sigma^{2}, \epsilon$ is independent across firms, and $\lambda(k)$ is the coefficient of efficiency of firm $k$. For a private firm, $\lambda(j)$ is normalized to be 1 . For an SOE, $\lambda(i)=\lambda$ with $0<\lambda \leq 1$. Thus, $\lambda$ is the total factor productivity of SOEs relative to private enterprises and is typically less than 1, reflecting lower efficiency of SOEs even when managerial efforts are the same in the two types of enterprises. The reason for this lies in various institutional constraints faced by the SOEs. For example, SOEs are subject to more government intervention 
than private enterprises and this lowers their efficiency. However, the main results of this paper do not depend on the assumption that $\lambda<1$.

The specification of $y$ assumes that $g$ is a pure public good. Although the essential point is made most clearly by assuming an infinite number of firms and the pure public good nature of $g(k)$, the qualitative features of our main results remain if the economy has a finite number of firms and stability has local effects; see Section 4 for example.

Before proceeding to our analysis, we need to make two assumptions on the production function $y(.,$.$) . The first one is rather standard, i.e.,$

Assumption 1: $y$ is increasing and concave in $s$ and $G$, and the cross partial derivative $y_{s G}>0$.

In order to capture the idea that stability is important for a firm's production, we assume that when $G$ is very small, $y_{G}$ is very large. We also assume that $y_{s}\left(T, G_{0}\right)>$ 1, which implies that monitoring is not very effective so that the effort enforced by monitoring is lower than that induced by proper incentives; see equation (1) below. For the analysis of the benchmark case, i.e., Proposition 1, we assume further that $y_{G}$ is small when $G$ is very large. Hence, we have a second assumption:

Assumption 2: $\lim _{G \rightarrow 0} y_{G}(s, G)=\infty$ for $s>0, \lim _{G \rightarrow \infty} y_{G}(s, G)=0$, and $y_{s}\left(T, G_{0}\right)>1$, where $y_{G}$ and $y_{s}$ are the first-order derivatives of $y$ with respect to $G$ and $s$, respectively.

We assume that managers are risk-neutral to focus on the main reason for the existence of SOE's in the model, i.e., SOEs provide public goods, rather than reduce the risk for agents. ${ }^{10}$ The owner/manager of a private enterprise keeps all the profit of the firm and his utility is:

$$
u(j)=y(s(j), G)-(s(j)+g(j)) .
$$

The manager of an SOE receives a fixed wage $w_{i}$ and his utility is:

$$
u(i)=w_{i}-(s(i)+g(i)) .
$$


The manager of a private firm will make no effort to contribute to the public good $G$ because the marginal cost of providing $g(j)$ is one and the marginal benefit is $y_{G}(s(j), G)$ multiplied by his marginal contribution to $G$. Since $G \geq G_{0}>0, y_{G}(s(j), G)<\infty$. Hence, the marginal benefit of $g(j)$ is very small because its marginal contribution to $G$ is negligible. It follows immediately that the manager of any private enterprise will not put in any stability maintenance effort. In addition, for any given level of general stability, the manager will choose production effort to maximize his profit. Because $y_{s}\left(T, G_{0}\right)>1$ by assumption 2 , optimal $s$ satisfies the first-order condition:

$$
y_{s}(s, G)-1=0
$$

and $s=s(G)>T$. Assumption 1 implies further that $s^{\prime}(G)>0$. Intuitively, the ownermanager keeps the profit of his firm and thus has an incentive to maximize profit. To do so, he allocates no effort to stability maintenance and all of his effort to production because his stability maintenance effort has only a small effect on profit while production effort has a non-trivial positive effect.

The manager of an SOE is willing to provide any level of public goods $g \leq T$ because, with a fixed salary, he expends a total level of $T$ effort and is indifferent to its allocation between production and stability maintenance. The former is due to the characteristics of government monitoring while the latter follows because the SOE manager's payoff does not depend on the profit of his firm and, consequently, on how his effort is allocated between the two tasks. Therefore, the manager of any SOE is assumed to do what is requested by the government so long as $s(i)+g(i)=T .^{11}$

The fundamental reason for the above results is that stability is a public good, which implies that the effect of a manager's stability maintenance effort on the profit of his firm is generally smaller than that of his production effort. So long as the manager's payoff depends on the profit of his firm, he will not fully take into account the externality of his stability maintenance effort and will provide too little of it. The government can mitigate the problem of under-provision of stability maintenance effort only by keeping some SOEs where the managers are paid fixed wages and monitored. The results of the 
above discussion are summarized in the following lemma.

Lemma 1: For a private firm, $g=0$ is the optimal choice. For an SOE, the manager is indifferent to any $g$ in $[0, T]$.

We assume that the objective of the government is to maximize the total social surplus that equals the unweighted sum of profits of all firms. The timing of events is as follows. First, the government chooses the percentage of SOEs in the economy, i.e., $p$, and makes a uniform effort choice, i.e., $g$, for stability maintenance and $T-g$ for production, for all managers of SOEs, given that the managers are indifferent to any effort choices satisfying $s+g=T$. Second, the owner-managers of private firms choose their production efforts, i.e., $s$.

Recall that equation (1) summarizes how the managers of private firms choose $s$ in response to the stability maintenance level $G$, which is the second stage of the game. Now, we analyze the first stage of the game, i.e., how the government chooses $p$ and $g$, which jointly determine $G$, in order to maximize the total social surplus:

$$
\pi \equiv p[\lambda y(T-g, G)-T]+(1-p)[y(s, G)-s]
$$

where $\lambda y(T-g, G)-T$ is the profit of an SOE, $y(s, G)-s$ is the profit of a private enterprise, and $G=p g+G_{0}$ is the level of social stability.

This section assumes that the owner-managers of private firms keep all the profits and the state maximizes the sum of profits of all enterprises. A motivation for this assumption is that the government is concerned with maintaining political control. Social welfare is an index of the average happiness of people in the society. Higher social welfare helps solidify the government's political control. In fact, these assumptions can be relaxed. Results similar to those in this section can be shown if we assume that the state taxes the profit of private enterprises and maximizes its revenue, i.e., the sum of taxes from private firms and profits from state-owned firms.

\subsection{The Benchmark Case}


We first study a benchmark case in which the government is able to rely on a social safety net to provide social stability rather than solely on SOEs. Alternatively, the benchmark case can be thought of as one in which the initial level of social stability, i.e., $G_{0}$, is very high so that social unrest is very unlikely. Not surprisingly, the optimal choice for the government is to have no SOEs, since private enterprises are more efficient. In other words, the benchmark case highlights the main reason for keeping SOEs, i.e., the need to provide public goods.

Proposition 1: When $G_{0}$ is sufficiently large, the optimal $p=0$.

Proof: The partial derivative of $\pi$ with respect to $p$ is:

$$
\frac{\partial \pi}{\partial p}=[\lambda y(T-g, G)-T-y(s, G)+s]+\lambda p g y_{G}(T-g, G)+(1-p) g y_{G}(s, G) .
$$

Notice that $\lambda y(T-g, G)-T<y(s, G)-s$, since the right-hand-side is the maximal profit of a private firm while the left-hand-side is strictly less than the maximal profit because the optimal $s(G)>T$. By Assumption $2, y_{G}(s, G)$ goes to 0 when $G \geq G_{0}$ goes to $\infty$. Therefore, the partial derivative of $\pi$ with respect to $p$ is negative for all $p$ when $G_{0}$ is sufficiently large. Q.E.D.

\subsection{The Main Case}

For the main case, we assume that $G_{0}$ is determined by history and it is very costly for the government to change its level in the short term. Furthermore, the initial level of $G_{0}$ is rather low. Then, we show that it is optimal to have some SOEs in the economy.

Proposition 2: When $G_{0}$ is sufficiently small, the optimal $p>0$.

Proof: We first prove that the optimal $g$ does not go to zero as $p$ approaches zero. The partial derivative of $\pi$ with respect to $g$ is:

$$
\frac{1}{p} \frac{\partial \pi}{\partial g}=-\lambda y_{s}\left(T-g, p g+G_{0}\right)+\lambda p y_{G}\left(T-g, p g+G_{0}\right)+(1-p) y_{G}\left(s, p g+G_{0}\right) .
$$


For $g \leq T-\delta$ and $\delta>0$, the first term above is bounded from below by $-\lambda y_{s}\left(\delta, p g+G_{0}\right)$. Because $\lim _{G \rightarrow 0} y_{G}(s, G)=\infty$ when $p$ and $G_{0}$ are both sufficiently small, the third term in equation (3) dominates and $\frac{\partial \pi}{\partial g}$ is positive. That is, for sufficiently small $G_{0}$, $\lim _{p \rightarrow 0} g \geq T-\delta$.

The partial derivative of $\pi$ with respect to $p$ is given by equation (2). To prove that the optimal $p>0$, we need to show that $\frac{\partial \pi}{\partial p}$ is positive for $p=0$. When $p \rightarrow 0$ and when $G_{0}$ is small enough, because $\lim _{p \rightarrow 0} g \geq T-\delta$, Assumption 2 implies that the last term in equation (2) is very large and dominates other terms. Therefore, the optimal $p$ is greater than 0. Q.E.D.

The intuition for this result is as follows. When $G_{0}$ is small, the marginal product of $G$ is large and it is desirable to increase the level of $G$ beyond $G_{0}$. Since it is extremely costly for the government to do, SOEs are used for this purpose.

An equally interesting question is under what conditions the government would choose to have some private enterprises. The simple condition is that either the effort level by a SOE manager $(T)$ or the total factor productivity of SOEs $(\lambda)$ relative to private enterprises is low. Under either condition, the opportunity cost of keeping a large proportion of SOEs, which is measured by the extra revenue from private enterprises, can be higher than the benefit of generating high public goods. To be precise, we have:

Proposition 3: When $T$ or $\lambda$ is sufficiently small, the optimal $p<1$ for all $G_{0}$.

Proof: When $p=1$,

$$
\frac{\partial \pi}{\partial p}=\lambda\left[y\left(T-g, g+G_{0}\right)+g y_{G}\left(T-g, g+G_{0}\right)\right]-T-\left[y\left(s, g+G_{0}\right)-s\right]
$$

which is negative when $T$ or $\lambda$ is small enough. Therefore the optimal $p<1$. Q.E.D.

The next proposition indicates that an SOE is less profitable than a private firm. This result highlights the idea that SOEs are maintained to promote social stability despite their low profitability.

Proposition 4: For any $p$ and $G_{0}$, an SOE produces less profit than a private firm. 
Proof: A private firm's profit is:

$$
y(s, G)-s,
$$

where $s$ is chosen to maximize the profit. An SOE's profit is:

$$
y(T-g, G)-T<y(T, G)-T<y(s, G)-s . \quad \text { Q.E.D. }
$$

We note that the basis for Proposition 4 is not the low total factor productivity, i.e., $\lambda$, of an SOE relative to a private firm. Even if $\lambda=1$, Proposition 4 still holds. Two factors are responsible for low profitability of an SOE. First, private firms free ride on SOEs for $G$ because $g>0$ in an SOE but $g=0$ in a private firm. Second, SOEs have lower profit incentives and therefore have a lower effort level, i.e., $T<s$. In other words, the poor financial performance of SOEs is endogenous.

\subsection{Comparative Statics}

We examine the effect of changes of $\lambda$ and $G_{0}$ on the optimal choice of $p$ and $g$. Intuitively, when $\lambda$, the relative total factor productivity of SOEs, is higher, the opportunity cost of keeping SOEs is lower so that we expect to see a larger proportion of SOEs. On the contrary, when $G_{0}$, the level of non-SOE provided public goods, is higher, the benefit of keeping SOEs is lower and we expect to see less SOEs at the optimum. These intuitive predictions are verified formally in the following proposition.

Proposition 5: Suppose $y_{s}(s, G)<\infty$. If $\lambda$ and $G_{0}$ are sufficiently small, the optimal $p$ has the following properties:

1) $\left.\frac{\partial p}{\partial \lambda}>0 ; 2\right) \frac{\partial p}{\partial G_{0}}<0$.

Proof: We first show that the optimal $p$ does not go to 1 as $\lambda$ goes to zero. For $p \geq 1-\delta$ and $\delta>0$, because $y_{G G}<0$, the last term in equation $(2)$ is:

$$
(1-p) g y_{G}(s, G) \leq \delta g y_{G}(s, p g) \leq \delta g y_{G}(s,(1-\delta) g)
$$

For sufficiently small $\lambda$, the right hand side of the above inequality and, thus, the last term of equation (2) are less than $T$. For all $p \geq 1-\delta$, equation (2) is negative if $\lambda$ is 
sufficiently small because $y(s, G)-s>0$. Therefore, the optimal $p$ is less than $1-\delta$ for small $\lambda$.

Next, we show that, when $\lambda$ and $G_{0}$ are sufficiently small, the optimal $g=T$. Since $p<1-\delta$ and $y_{s}$ is bounded from above, when $\lambda$ and $G_{0}$ are sufficiently small, the third term of the right hand side of equation (3) dominates so that $\partial \pi / \partial g$ is positive for all $g$. Therefore, the optimal $g=T$.

¿From Propositions 2 and 3, equation (2) holds at the optimal $p$. Since $g=T$ is a constant, the optimal $p$ is determined by equation (2) only. Checking the MilgromWilson condition, we have:

$$
\frac{\partial^{2} \pi}{\partial p \partial \lambda}=y(T-g, G)+p g y_{G}(T-g, G)>0
$$

Therefore, $\frac{\partial p}{\partial \lambda}>0$.

$$
\frac{\partial^{2} \pi}{\partial p \partial G_{0}}=\lambda y_{G}(T-g, G)-y_{G}(s, G)+\lambda p g y_{G G}(T-g, G)+(1-p) g y_{G G}(s, G),
$$

where, the last two terms are negative by assumption; $\lambda y_{G}(T-g, G)-y_{G}(s, G)<0$ because $y_{s G}>0$. Therefore, $\frac{\partial^{2} \pi}{\partial p \partial G_{0}}<0$. This implies that, $\frac{\partial p}{\partial G_{0}}<0$. Q.E.D.

\section{Government Provision of $G$}

Our analysis has assumed a fixed level of $G_{0}$. In this section, we extend the model by endogenizing the government's choice of $G_{0}$. We show that, if the cost to the government for providing $G$ directly is high, as it might be in the initial stages of transition, the government will not provide sufficient $G$ and, as a result, SOEs are maintained to provide $G$. However, if the cost to the government for providing $G$ is sufficiently low, it is efficient for the government to be the only provider of $G$ and SOEs are not needed.

Denote $G_{0}=G_{1}+G_{2}$ where $G_{1}$ is the initial level of stability and $G_{2}$ is the government's effort to augment stability. Assume that the cost of government effort is $\mu \phi\left(G_{2}\right)$, where $\phi$ is a strictly increasing and convex function. Incorporating the government's choice of $G_{2}$ into consideration, the optimization problem becomes: 


$$
\begin{aligned}
\max _{p, g, G_{2}} \omega & \equiv p[\lambda y(T-g, G)-T]+(1-p)[y(s, G)-s]-\mu \phi\left(G_{2}\right) \\
\text { s.t. } \quad G & =G_{1}+G_{2}+p g \\
s & =\arg \max [y(s, G)-s]
\end{aligned}
$$

The following proposition characterizes the optimal solution:

Proposition 6: Suppose $G_{1}$ is positive but sufficiently small. (1) If $\mu$ is sufficiently large, the optimal $p>0$. (2) If $\mu$ is sufficiently small, the optimal $p=0$.

Proof: The government's maximization problem can be divided into two steps. In step 1 , for a given value of $G_{2}$, choose $(p, g)$ optimally subject to the constraints. Denote the maximum value by $\omega\left(G_{2}\right)=\pi\left(G_{2}\right)-\mu \phi\left(G_{2}\right)$. By the envelope theorem, we have:

$$
\pi^{\prime}\left(G_{2}\right)=p \lambda y_{G}(T-g, G)+(1-p) y_{G}(s, G)
$$

In step 2 , choose $G_{2}$ to maximize $\omega\left(G_{2}\right)$.

By Proposition 1, there exists a $G_{2}^{\prime}$ such that the optimal $p=0$ if $G_{2}>G_{2}^{\prime}$. Let $B_{1}>0$ be the minimum value of $\pi^{\prime}\left(G_{2}\right)$ over the closed interval $\left[0, G_{2}^{\prime}\right]$. If $\mu$ is sufficiently small so that $\mu \phi^{\prime}\left(G_{2}^{\prime}\right)<B_{1}, \omega^{\prime}\left(G_{2}\right)>0$ for $G_{2} \leq G_{2}^{\prime}$, which implies that the government should choose $G_{2}>G_{2}^{\prime}$. Given such a choice of $G_{2}$, the optimal $p=0$. Thus, we have proven part (2) of the proposition.

For $G_{2}>G_{2}^{\prime}$, the optimal $p=0$. Then $\pi\left(G_{2}\right)=\max [y(s, G)-s]$, which can be easily shown to be concave in $G_{2}$ because $y$ is assumed to be concave in $(s, G)$. Consequently, $\pi^{\prime}\left(G_{2}\right)$ decreases for $G_{2}>G_{2}^{\prime}$ and, therefore, the maximum value of $\pi^{\prime}\left(G_{2}\right)$ over the interval $[0, \infty)$ is the same as that over the closed interval $\left[0, G_{2}^{\prime}\right]$. Because $G_{1}>0$, $\pi^{\prime}\left(G_{2}\right)$ is continuous over the closed interval $\left[0, G_{2}^{\prime}\right]$ and, therefore, has a finite maximum value over the interval. Denote the maximum value by $B_{2}$.

By Proposition 2, there exists a $G_{2}^{\prime \prime}$ such that the optimal $p>0$ if $G_{2}<G_{2}^{\prime \prime}$. If $\mu$ is sufficiently large so that $\mu \phi^{\prime}\left(G_{2}^{\prime \prime}\right)>B_{2}, \omega^{\prime}\left(G_{2}\right)<0$ for all $G_{2} \geq G_{2}^{\prime \prime}$, which implies that 
the government's optimal choice of $G_{2}$ is less than $G_{2}^{\prime \prime}$. Given such a choice of $G_{2}$, the optimal $p>0$, which proves part (1) of the proposition. Q.E.D.

The above analysis shows that, if it is possible for the government to enhance directly social stability at the beginning of transition by expending tax revenue, the government may or may not choose to expend a sufficient amount of resources on maintaining stability. When the government's cost of providing this public good is very high, it is not worthwhile for the government to do so even if it has enough tax revenue. As a result, SOEs are kept unreformed to provide social stability. Only when the government's cost of providing the public good is low enough will SOEs be reformed and social stability be maintained from tax revenue only.

\section{Employment as a Public Good}

In the model analyzed in Section $2, g$ is the effort of a firm that increases the revenue of all firms in the economy and called the stability maintenance effort. We gave several examples of this effort including employment. When severe unemployment threatens social stability, increasing employment helps to maintain social stability and, therefore, has a positive effect on all firms in the economy. In this section, we consider a variation of this model to reflect better this interpretation of $g$. For simplicity, we abstract from any direct government provision of $G$.

Assume that the revenue of each firm is:

$$
x(k)=y[s(k), l(k), G]-l(k) w+\epsilon(k),
$$

where $l(k)$ is the labor input of the firm, $w$ is the market wage, $G={ }_{k}^{\mathrm{R}} l(k) d k$ is the total level of employment in the economy, and all other variables are the same as those in the previous model. The function $y$ is assumed concave in $(s, l, G)$ and $s, l, G$ are pair-wise complementary. The economy we consider is one with significant excess labor supply. The wage does not clear the labor market and is not affected significantly by labor demand. Therefore, we assume that the wage $w$ does not depend on $G$. 
In the basic model, a firm's effort $g$ has the same effect on its own revenue as it does on other firms' revenue. In contrast, under the current setup, a firm's labor input $l$ has a stronger effect on the firm's own revenue than on other firms' revenue; that is, $l$ has a positive local effect. This difference between the previous model and the current model makes the analysis sufficiently different to warrant separate treatment.

The manager of an SOE is paid a fixed wage and the wage for employees does not affect the manager's payoff. Therefore, the manager chooses $s=T$ and is indifferent about the choice of $l(k)$. Then, the manager will choose the labor input following the government's instruction. Denote the level of labor input that the government instructs the manager to choose by $L$.

The owner/manager of a private firm maximizes profit. We assume that the government cannot subsidize employment in private firms or force these firms to keep a certain level of employment. If the government did subsidize employment or had an employment quota, the firms would have incentives to create false employment to get the subsidy or to fulfill the quota. Furthermore, rules against firing of workers do not work because the firm could make an unwanted worker's life in the firm so unpleasant that he would quit instead of waiting for the firm to fire him. Given this assumption, the labor input $l(j)$ and the effort level $s(j)$ are chosen by the owner/manager to maximize:

$$
y[s(j), l(j), G]-s(j)-w l(j),
$$

where $G=p L+(1-p) l^{e}$ and $l^{e}$ is manager $j$ 's expectation of other private firms' labor input. The equilibrium conditions are:

$$
\begin{gathered}
y_{s}\left[s, l, p L+(1-p) l^{e}\right]=1 \\
y_{1}\left[s, l, p L+(1-p) l^{e}\right]=w \\
l=l^{e} .
\end{gathered}
$$

Denote the solution by $s(p, L)$ and $l(p, L)$. From equilibrium conditions $(6)$, when $p=0$, $s(0, L)$ and $l(0, L)$ do not depend on $L$. Denote $s(0, L)$ by $s_{0}$ and $l(0, L)$ by $l_{0}$. In this case, $G_{0}=l_{0} \cdot{ }^{12}$ 
The government chooses $p$ and $L$ to maximize total social welfare:

$$
\pi=p[y(T, L, G)-T-w L]+(1-p)[y(s(p, L), l(p, L), G)-w l(p, L)-s(p, L)],
$$

where $G=p L+(1-p) l(p, L)$. For simplicity, we have assumed implicitly that the only social benefit of employment is through the production function. In reality, there are other direct benefits, especially when the labor market does not clear so that there is unemployment. We omit these direct benefits to focus on our main point. When these direct effects are included, there will be a stronger case for our main result that it is optimal to retain some SOEs under certain conditions. Specifically, our main results can be stated as:

Proposition 7: The optimal $p$ is positive provided that $y_{G}\left(s_{0}, l_{0}, G_{0}\right)$ is sufficiently large. In this case, SOEs employ more workers and generate less profits than private firms.

Proof: To facilitate exposition, we first introduce the notation that:

$$
V(G) \equiv \max _{s, l} y(s, l, G)-s-w l
$$

which is an increasing function of $G$, because the Envelope Theorem implies that $V^{\prime}(G)=$ $y_{G}(s, l, G)>0$. With this notation, the total social surplus when there are no SOEs is:

$$
\pi(0)=V\left(G_{0}\right)
$$

and the total social surplus when $p>0$ and $L=l_{0}+l_{1}$ for some $l_{1}>0$ is:

$$
\pi(L, p)=p[y(T, L, G)-T-w L]+(1-p) V(G)
$$

where $G=p L+(1-p) l\left(p, l_{0}+l_{1}\right)$. Due to the complementarity between $s, l$, and $G$, it can be shown straightforwardly that $l\left(p, l_{0}+l_{1}\right) \geq l_{0}$ for any positive $p$ and $l_{1}$, provided that the solution to equilibrium conditions (6) is unique and stable. Then, 
$G \geq p L+(1-p) l_{0}=G_{0}+p l_{1}$. Take the difference between $\pi(L, p)$ and $\pi(0)$, we have:

$$
\begin{aligned}
& \pi(L, p)-\pi(0) \\
= & p\left[y(T, L, G)-T-w L-V\left(G_{0}\right)\right]+(1-p)\left[V(G)-V\left(G_{0}\right)\right] \\
\geq & p\left[y\left(T, L, G_{0}\right)-T-w L-V\left(G_{0}\right)\right]+(1-p)\left[V\left(G_{0}+p l_{1}\right)-V\left(G_{0}\right)\right] \\
= & p\left[y\left(T, L, G_{0}\right)-T-w L-V\left(G_{0}\right)\right]+(1-p) V^{\prime}\left(G_{2}\right) p l_{1},
\end{aligned}
$$

where the inequality results from $G \geq G_{0}+p l_{1}>G_{0}$ and the fact that $y$ and $V$ increase with $G$. The last equality is a result of applying the Mean Value Theorem, with $G_{2}$ being some number between $G_{0}$ and $G_{0}+p l_{1}$. By the Envelope Theorem, $V^{\prime}\left(G_{2}\right)=y_{G}\left(s_{2}, l_{2}, G_{2}\right)$, where $s_{2}$ and $l_{2}$ are the optimal choice by the owner/manager of the private firm for the given $G_{2}$. Suppose $y_{G}\left(s_{0}, l_{0}, G_{0}\right)$ is sufficiently large so that:

$$
y_{G}\left(s_{0}, l_{0}, G_{0}\right)>l_{1}^{-1}\left[V\left(G_{0}\right)+T+w\left(l_{0}+l_{1}\right)-y\left(T, l_{0}+l_{1}, G_{0}\right)\right]
$$

for some positive $l_{1}$. Because $0<G_{2}-G_{0}<p l_{1}$ and $\left(s_{2}\left(G_{2}\right), l_{2}\left(G_{2}\right)\right)$ are continuous in $G_{2}$, for sufficiently small $p,\left(s_{2}, l_{2}, G_{2}\right)$ is very close to $\left(s_{0}, l_{0}, G_{0}\right)$. Consequently, $(1-$ p) $y_{G}\left(s_{2}, l_{2}, G_{2}\right)$ is very close to $y_{G}\left(s_{0}, l_{0}, G_{0}\right)$ so that:

$$
(1-p) y_{G}\left(s_{2}, l_{2}, G_{2}\right)>l_{1}^{-1}\left[V\left(G_{0}\right)+T+w L-y\left(T, L, G_{0}\right)\right]
$$

Then,

$$
\pi(L, p)-\pi(0)>0
$$

Therefore, the optimal proportion of SOEs, $p$, is positive.

The profit produced by an SOE is $\pi_{1}=y(T, L, G)-T-w L$ and that produced by a private firm is $\pi_{2}=V(G)=V[p L+(1-p) l(p, L)]$. Since $\pi_{2}$ is the value of $y(s, l, G)-s-w$ when $s$ and $g$ are optimally chosen while $\pi_{1}$ is the value of the same function when $s$ and $g$ are suboptimal, $\pi_{2}>\pi_{1}$. The derivative of the total social surplus, $\pi$, with respect to $p$ is:

$$
\frac{\partial \pi}{\partial p}=\pi_{1}-\pi_{2}+\left[p y_{G}(T, L, G)+V^{\prime}(G)\right] \frac{\partial G}{\partial p} .
$$


Because the optimal $p$ is positive, $\frac{\partial \pi}{\partial p} \geq 0$ at the optimum. Then $\frac{\partial G}{\partial p}>0$ at the optimum; that is, total employment increases with the proportion of SOEs. This can only happen when $L>l(p, L)$, or in other words, when each SOE employs more workers than each private firm. Q.E.D.

\section{Empirical Evidence}

Since our research is motivated by China's experience of state enterprise reform, our empirical evidence comes from China. Future empirical research on other transition economies is needed in order to confirm the more general relevance of our theoretical analysis. Some of the evidence presented below justifies the assumptions of our analysis, i.e., social stability is important to economic growth and it is a public good. Other evidence validates the main prediction of the model, that is, the reformist government made a conscious choice of slowing down SOE reform and instructed SOEs to continue contributing to social stability, which led to the poor performance of SOEs during the transition.

The premise of our theory is that social stability is intrinsically important for economic growth and that, during reform, there are threats to social stability. Investors, especially foreign investors, tend to be very sensitive to social stability. In surveys, Western investors in emerging market economies often list social stability as the leading factor affecting their choice of investment location. Among the threats to social stability in transition economies, massive unemployment is one of the most prominent. In the Chinese context, the unemployment problem is particularly acute. As labor market mobility improved during the reform, approximately 100 million Chinese peasants left their rural residence to search for jobs in cities. Meanwhile, efforts to improve SOEs' efficiency led invariably to large layoffs, not only because SOEs have had large amounts of surplus workers traditionally but also because many SOEs were making unwanted products and should be liquidated. Some studies estimate that 20 to 30 percent of the total labor supply in China's SOEs is redundant (Wang, 1996). 
China's reformist leaders understand the importance of maintaining social stability for the success of reform. Specifically, they have made it very clear that they do not see mass layoffs as an appropriate solution to the surplus labor problem in SOEs. In an important speech on SOE reform in 1997, then vice Premier (and now Premier) Zhu Rongji stressed that excessive workers in SOEs should not be resolved through massive layoffs. Also cases of bankruptcy of SOEs should be dealt with more aggressively by using mergers to minimize the social impact of unemployment that bankruptcy will cause. Zhu Rongji also instructed the state banks to reduce interest payments for those SOEs searching for new ways to re-employ their excessive labor. Vice Premier Wu Bangguo, who is in charge of SOE reform, proclaimed that the government should take it as an extremely important responsibility that workers under furlough from financially distressed SOEs are re-employed and their basic livelihood is guaranteed (Wu, 1997).

However, unlike the case of developed market economies in which designated government agencies provide social welfare services, it was the SOEs that had been the main providers of most social welfare programs before reform. During reform, they continue to play the same role. "Many Chinese state enterprises have long operated as socialwelfare institutions, with canteens, hospitals and schools all operating on one budget." (Asian Wall Street Journal or AWSJ, July 13, 1998, p. 3.) Establishing separate government agencies to provide a social safety net can not be accomplished overnight. As early as 1990, when the Chinese government was drafting the eighth five-year plan, it emphasized the importance of establishing a social security system. Towards the end of the decade, an AWSJ article commented that "Beijing has yet to roll out a nationwide pension system, leaving many workers laid off without adequate medical and housing benefits." (AWSJ, August 6, 1998, p. 5.) In a front-page editorial, the People's Daily said, ...[t] he speedy liquidation of state enterprises has generated more layoffs than the government re-employment programs can handle, ...'In some areas, this has led to serious social problems.' (Quoted in AWSJ, August 6, 1998, p. 5.)

Our theory predicts that private enterprises do not have any incentives to employ 
surplus labor to help maintain social stability and this is indeed the case in China. As noted in a report by China's State Economic and Trade Commission, local governments had overemphasized selling SOEs as a tool of reform. The practice has exerted negative impact on local economic development and social stability because "the first thing private owners typically do to turn around unprofitable enterprises is to cut loose their bloated work-forces." (AWSJ, July 13, 1998, p. 3.) As can be anticipated, "[m] ounting layoffs have resulted in scattered labor protests throughout the country." (AWSJ, August 6, 1998, p. 5.)

A main prediction of the theory is that SOEs are instructed to retain employment so as to help maintain social stability and, as a result, the performance of SOEs suffer. In a survey of 769 Chinese SOEs in 1990, managers were asked why they continue to produce products that lose money. More than 60 percent of those managers who responded listed direct employment considerations for workers as "important" and "very important" reasons (see Table 1). The other reasons for overproduction, "forced by the government" and "getting subsidies from the government", are also employment-related. To provide employment, many Chinese SOEs continue to produce apparently obsolete, un-competitive and money-losing products. Over 30 percent of state enterprises are making financial loss and relying on government subsidies (Bai and Wang, 1998).

\section{(Insert Table 1 Here)}

A rather creative way for Chinese SOEs to help maintain social stability while undergoing restructuring is called xia gang. For cases in which paying workers for doing nothing is more beneficial than continuing to keep them in productive service, workers are paid an amount for living expenses by the SOE to "step down from their post" (xia gang). A worker in xia gang status still enjoys all the standard welfare provisions of the SOE. In 1996, workers in the SOEs in xia gang status reached nine million, which accounts for roughly fifteen percent of total employment in SOEs. The meager living expense paid to xia gang workers is only a small fraction of the cost to support these 
worker because of the high benefits that they receive, such as heavily subsidized company housing and full or almost complete medical coverage. In a typical Chinese SOE, the ratio of welfare-provision-assets, e.g., company housing, company-run child-care and schools, and sports facilities, to total-assets reaches 35 to 40 percent. Welfare benefits in monetary forms reach more than 50 percent of the total wage bill (see Liu, 1995).

Overall, with various measures taken by the government during the reform era, Chinese SOEs have not only avoided major layoffs but also increased total employment until very recently. As the figures in Table 2 show, total employment in the SOEs increased by more than 25 percent between 1980 and 1992 and stayed stable between 1992 and 1997. In recent years, despite the significant slow down of SOE output growth, the total employment of SOEs has not decreased much. The SOEs have made a major contribution to keeping surplus labor in the economy and off the streets.

\section{(Insert Table 2 Here)}

The comparative statics in Proposition 5 predict a positive correlation between the existing level of social instability and the speed of privatization but a negative relationship between the relative efficiency of the SOEs and the speed of privatization. This

is consistent with recent observations of the development of privatization in China. ${ }^{13}$ ¿From 1993 through 1997, the Chinese economy experienced a period of declining inflation rates and high real growth. During this time, SOEs became increasingly inefficient (Bai and Wang, 1998). In September 1997, the Fifteenth Party Congress called for speeding up the reforms of SOEs. However, the adverse impact of Asian financial crises threatened China's export markets and deflation replaced inflation in domestic and foreign markets. Economic growth slowed and the pressure of unemployment and therefore social instability mounted. Not surprisingly, the government took measures to slow down privatization of the SOEs. (AWSJ, July 13, 1998, p. 3.)

\section{Concluding Remarks}


This paper presents a multi-task theory of state enterprise reform. SOEs are charged with not only the task of efficient production but also the task of social welfare provision. The theory starts with the observation that, during transition, maintaining employment or providing a social safety net to the unemployed are important to social stability, which in turn is crucial for the productivity of the whole economy. However, independent institutions for a social safety net are lacking and firms with strong profit incentives have little incentive to promote social stability due to its public good nature. Therefore, it is inevitable that SOEs continue to play their multi-task role during the transition. Accompanying the multi-task objectives of SOEs, low-powered incentives continue to be imposed on the SOEs so that SOE restructuring is delayed.

The multi-task theory has two simple implications. First, it implies that the SOE reform and the economic performance of the SOEs cannot be satisfactory unless their social welfare task is taken over by independent social welfare institutions. ${ }^{14}$ Second, the desirable pace of SOE reform has to take into account the speed of emergence of supporting institutions, in particular, those replacing the functions of the SOEs that are unrelated to efficient production. ${ }^{15}$ 
Table 1: Reasons for Producing Money-Losing Products.

(Unit: Percentage of Responses by Enterprise Directors.)

Not I mpt I mportant Very I mpt Score Ranking

(Unit: Percentage of Responses by Enterprise Directors.)

$\begin{array}{llllll}\text { "'Forced'' } & 31.3 & 23.5 & 24.8 & 1.53 & 0.692 \\ \text { "Lack of Tech.' } & 36.0 & 33.1 & 12.7 & 1.40 & 0.627 \\ \text { "Subsidy'' } & 40.4 & 19.8 & 11.9 & 1.16 & 0.600 \\ \text { "Employment'" } & 20.8 & 31.8 & 30.4 & 1.76 & 0.675\end{array}$

Weight

12

2

3

Notes: The table is based on answers to the survey question: "Why Do You Produce Money-Losing Products?" The survey was conducted with 769 SOEs from 1980 to 1989. See Li (1997) for details. The complete description of the choices are: "Forced" = "forced by the government"; "Lack of Tech." = "lack of technology"; "Subsidy" = "according to current government policies, we benefit from producing these products"; "Employment" $=$ "in order to provide jobs for surplus workers." Enterprises directors were asked to evaluate each choice ("Forced", ...) by using a mark, such as: "Not important" ... The score is defined as each choice's weighted average mark across all enterprises, with the reported weight in the table. The ranking is the frequency with which an enterprise director chose this option as the highest mark among all choices although ties were possible. 
Table 2: Total Employment of China's State Sector

(Unit: Million)

$\begin{array}{lrrrrrrr}\text { Year } & 1980 & 1981 & 1982 & 1983 & 1984 & 1985 & 1986 \\ \text { Employment } & 80.19 & 83.72 & 86.30 & 87.71 & 86.37 & 89.90 & 93.33 \\ & & & & & & & \\ \text { Year } & 1987 & 1988 & 1989 & 1990 & 1991 & 1992 & 1993 \\ \text { Employment } & 96.54 & 99.84 & 101.08 & 103.46 & 106.64 & 108.89 & 109.20 \\ & & & & & & & \\ \text { Year } & 1994 & 1995 & 1996 & 1997 & & & \\ \text { Employment } & 108.90 & 109.55 & 109.49 & 107.66 & & & \\ & & & & & & & \end{array}$

Note: The source is China Statistic Year Book 1995 and China Statistic Year Book 1998. 


\section{R eferences}

Bai, Chong-en, Li, David D., and Wang, Yijiang, "Enterprise Productivity and Efficiency: When Is Up Really Down?" J . Comp. Econom. 24, 3:265-280, June 1997.

Bai, Chong-en, Li, David D., Tao, Zhigang, and Wang, Yijiang, "A Multi-Task Theory of the State Enterprise Reform." Unpublished Manuscript, The University of Hong Kong, Dec. 1999.

Bai, Chong-en, and Tao, Zhigang, "Contract Mixing in Franchising as a Mechanism for Public Good Provision." J ournal of Economics and Management Strategy 9, 1:85-113, Spring 2000.

Bai, Chong-en, and Wang, Yijiang, "Bureaucratic Control and the Soft Budget Constraint." J . Comp. E conom. 26, 1:41-61, Mar. 1998.

Castanheira, Micael, and Roland, Gérard, "Restructuring and Capital Accumulation in Transition Economies: A General Equilibrium Perspective." Discussion Paper No. 1372. Centre for Economic Policy Research, April 1996.

Castanheira, Micael, and Roland, Gérard, "The Optimal Speed of Transition: A General Equilibrium Analysis." International Economic Review 41, 1:219-239, Feb. 2000 .

Dewatripont, Mathias and Roland, Gérard, "Economic Reform and Dynamic Political Constraints." Rev. E conom. Stud. 59, 4:703-730, Oct. 1992.

Dewatripont, Mathias and Roland, Gérard, "The Virtues of Gradualism and Legitimacy in the Transition to a Market Economy." Econom. J . 102, 411:291-300, Mar. 1992.

Dewatripont, Mathias and Roland, Gérard, "Transition as a Process of Large-Scale Institutional Change." In D. Kreps and K. Wallis, Ed., Advances in E conomics and E conometrics: Theory and A pplications. Vol. 2, pp. 240-278, Cambridge University Press, 1997. 
Gordon, Roger H., and Li, David D., "The Effects of Wage Distortions on Transition: Theory and Evidence from China." European Econom. Rev. 43, 1:163-183, Jan. 1999.

Holmstrom, Bengt, and Milgrom, Paul, "Multitask Principal-Agent Analyses: Incentive Contracts, Asset Ownership and Job Design." J ournal of Law, Economics and Organization 7, Special Issue, 24-52, 1991.

Holmstrom, Bengt, and Milgrom, Paul, "The Firm as an Incentive System." A merican Economic Review 84, 4:972-991, Sept. 1994.

Jefferson, Gary, and Rawski, Thomas, "Enterprise Reform in Chinese Industry." J . E conom. Perspect. 8, 2:47-70, Spring 1994.

Kornai, Janos, The Socialist System: The P olitical E conomy of Communism. Princeton University Press, 1992.

Li, David D., "Government Control During Transition: Theory and Evidence from China." Mimeo, Department of Economics, University of Michigan, 1997.

Liu, Shijing, "Zhong Guo Guo You Qi Ye de Xing Zhi Yu Gai Ge Luo Ji." ("The Nature of SOEs and the Logic of Reform.") J ing J i Yan Jiu (Econom. Res.), No. 4, 29-36, Apr. 1995.

McMillan, John, "Markets in Transition." In D. Kreps and K. Wallis, Ed., Advances in Economics and Econometrics: Theory and Applications. Vol. 2, pp. 210-239, Cambridge University Press, 1997.

Murrell, Peter, and Wang, Yijiang, "When Privatization Should be Delayed: The Effect of Communist Legacies on Organizational and Institutional Reforms." J . Comp. Econom. 17, 2:385-406, June 1993.

Qian, Yingyi, "Enterprise Reform in China: Agency Problems and Political Control." Economics of Transition 4, 2:427-448, Oct. 1996.

Qian, Yingyi and Xu, Changgang, "Why China's Economic Reforms Differ: the MForm Hierarchy and Entry/Expansion of the Non-State Sector." E conomics of Transition 1, 2:135-70, June 1993. 
Roland, Gérard, and Verdier, Thierry, "Transition and the Output Fall." Economics of Transition 7, 1:1-28, Jan. 1999.

Wang, Cheng, "Zhong Guo Jiu Ye Zhuan Yi: Zun Yi Xin Shi Ye, Jiu Ye Bu Zu Dao Xiao Lui Xing Jiu Ye." ("The Transformation of Employment in China: Implicit Unemployment, Underemployment, and Efficient Employment.") J ing J i Y an J iu (E conom. Res.), No. 5, 38-46, May 1996.

Woo, Wing Thye, Fan, Gang, Hai, Wen, and Jin, Yibiao, "Efficiency and Macroeconomic Consequences of Chinese Enterprise Reform." China Econom. Rev. 4, 2:153-168, June 1993.

Woo, Wing Thye, Hai, Wen, Jin, Yibiao, and Fang, Gang, "How Successful Has China's State Enterprise Reform Been?" J . Comp. E conom. 18, 3:410-437, June 1994.

$\mathrm{Wu}$, Bangguo, "Making Tireless Efforts to Provide Re-employment and Reduce UnemploymentRelated Poverty." People's Daily (Overseas Edition), May 29, 1997.

Zhu, Rongji, "How to Resolve the Difficulties of the SOE?" People's Daily (O verseas Edition), Jan. 9, 1997. 


\section{Endnotes}

1. This is a revised version of our earlier working paper titled "State Enterprises in Transition: A Multi-Task Perspective." We thank John Bonin, two anonymous referees, participants of the William Davidson Institute's 1997 Workshop and 1997 AEA Meetings for their many helpful comments. We would also like to thank Roger Gordon, Yingyi Qian, Gerard Roland, Jan Svejnar, and Chenggang Xu for earlier discussions on the topic. Partial financial supports from the URC research grant of HKU (Chong-En Bai), DAG99/00/BM24 and the Chinese SOE project of the HLCOR of the HKUST (David Li), the Research Grants Council of Hong Kong (Zhigang Tao), and the Graduate School's Grant-in-Aid, University of Minnesota (Yijiang Wang) are gratefully acknowledged.\}

2. An extension to incorporate product market competition can also be made. For details please see an earlier version of this paper (Bai, Li, Tao and Wang, 1999).

3. Bai and Tao (2000) take a similar perspective to explain the co-existence of headquarters owned and independently owned branches in franchising. Their model pays close attention to the context of franchising and is very different from the one in this paper.

4. In the context of dealing with the problem of social instability associated with unemployment, it is often suggested that a payroll-type tax be levied so that the employed pay taxes to be used to subsidize the unemployed as an insurance device. Such a scheme can not substitute for the role of SOEs because without the social services of SOEs, it is very costly to compensate an unemployed worker. Given the high cost, we show that the government is likely not to rely on such taxes in Section 3. Furthermore, with the incidence of the tax born partly by the enterprise, this actually induces more unemployment and is counter-productive. Hence, despite such insurance schemes, reforms of SOEs are still slow in reality.

5. We acknowledge an anonymous referee for pointing this out to us. 
6. In other words, we discuss the incentives of the providers rather than the recipients of social welfare.

7. Two excellent surveys on transition are Dewatripont and Roland (1997) and McMillan (1997).

8. We thank an anonymous referee for suggesting the extension.

9. In that paper, we incorporate the interaction between the SOEs and private enterprises via product market competition. The introduction of private enterprises in transition economies increases product market competition and thereby affects adversely the performance of state-owned enterprises. The ensuing question is whether the government should keep any state-owned enterprise in these circumstances. Presumably, the provision of social stability by the SOEs enhances the incentive for effort of private enterprises due to the complementarity between social stability effort and production effort. Meanwhile, due to product market competition, the financial performance of the SOEs deteriorates. We show that, under reasonable conditions, the former dominates the latter and, hence, it is optimal to keep some SOEs in transition economies.

10. We do not assume that the workers are risk-neutral. In fact, we assume implicitly that they are risk averse and care about the social safety net. We assume only that managers are risk-neutral. Our results remain valid even if the managers are risk averse. The proof is available upon request.

11. Notice that $T$ is the effort level that is exerted by managers without incentive contracts. Therefore, it is not as high as those of the managers of private enterprises who face high-powered incentives.

12. The notation $G_{0}$ here has a slightly different meaning from that in Section 2. In both places, $G_{0}$ is the level of stability when $p=0$ but here it is not the initial level of stability as defined in Section 2. 
13, Another interesting episode was the early 1980's, tens of millions of urban high school graduates, who were sent to the country-side during the Cultural Revolution, returned to the cities waiting for urban employment. The mounting potential for social instability prevented any major SOE reform from being implemented. Indeed, largescale SOE reform started only after the mid-1980's when this social stability issue subdued.

14. This view predicts poor economic performance of SOEs during reform, contrary to what Jefferson and Rawski (1994) have argued. For the debate on China's SOE reform, see Woo et al (1993), Woo et al (1994), and Bai, Li, and Wang (1997).

15. See Kornai (1992) for a philosophical discussion of this view. Murrell and Wang (1993) provide a general analysis. 


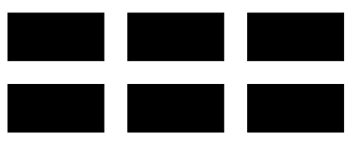

THE WiLliam DAVIDSON INSTITUTE

AT THE UNIVERSITY OF MICHIGAN BUSINESSSCHOOL

\section{DAVIDSON INSTITUTE WORKING PAPER SERIES - Most Recent Papers}

The entire Working Paper Series is available at: www.wdi.bus.umich.edu

CURRENT AS OF 4/4/01

\begin{tabular}{|c|c|c|}
\hline Publication & Authors & Date \\
\hline No. 367 A Multi-Task Theory of the State Enterprise Reform & $\begin{array}{l}\text { Chong-En Bai, David D. Li, } \\
\text { Zhigang Tao, and Yijiang Wang }\end{array}$ & Mar. 2001 \\
\hline No. 366 Confidence Building in Emerging Stock Markets & $\begin{array}{l}\text { Enrico C. Perotti, Luc Laeven, } \\
\text { and Pieter van Oijen }\end{array}$ & Dec. 2000 \\
\hline $\begin{array}{l}\text { No. } 365 \text { Incentive Contracting versus Ownership Reforms: Evidence } \\
\text { from China's Township and Village Enterprises }\end{array}$ & $\begin{array}{l}\text { Chun Chang, Brian McCall, and } \\
\text { Yijang Wang }\end{array}$ & Nov. 2000 \\
\hline $\begin{array}{l}\text { No. } 364 \text { Individual Pay and Outside Options: Evidence from the Polish } \\
\text { Labour Force Survey }\end{array}$ & $\begin{array}{l}\text { Fiona Duffy and Patrick Paul } \\
\text { Walsh }\end{array}$ & Mar. 2001 \\
\hline $\begin{array}{l}\text { No. } 363 \text { Investment, Credit Rationing and the Soft Budget Constraint: } \\
\text { Evidence from Czech Panel Data (revised Davidson Institute Working } \\
\text { Paper No. 60a) }\end{array}$ & Lubomír Lízal and Jan Svejnar & Feb. 2001 \\
\hline $\begin{array}{l}\text { No. } 362 \text { A Network Perspective on Inter-Organizational Transfer of } \\
\text { R\&D Capabilities: A Study of International Joint Ventures in Chinese } \\
\text { Automobile Industry }\end{array}$ & $\begin{array}{l}\text { Zheng Zhao, Jaideep Anand and } \\
\text { Will Mitchell }\end{array}$ & Feb. 2001 \\
\hline $\begin{array}{l}\text { No. } 361 \text { Network Restructuring and Firm Creation in East-Central } \\
\text { Europe: A Public-Private Venture }\end{array}$ & Gerald A. McDermott & Dec. 2000 \\
\hline $\begin{array}{l}\text { No. } 360 \text { Responses of Private and Public Schools to Voucher Funding: } \\
\text { The Czech and Hungarian Experience }\end{array}$ & $\begin{array}{l}\text { Randall K. Filer and Daniel } \\
\text { Münich }\end{array}$ & Oct. 2000 \\
\hline $\begin{array}{l}\text { No. } 359 \text { Labor Market Uncertainty and Private Sector Labor Supply in } \\
\text { Russia }\end{array}$ & Steven Stillman & Sept. 2000 \\
\hline $\begin{array}{l}\text { No. } 358 \text { Russian Roulette-Expenditure Inequality and Instability in } \\
\text { Russia, 1994-1998 }\end{array}$ & Branko Jovanovic & Sept. 2000 \\
\hline No. 357 Dealing with the Bad Loans of the Chinese Banks & John P. Bonin and Yiping Huang & Jan. 2001 \\
\hline No. 356 Retail Banking in Hungary: A Foreign Affair? & John P. Bonin and István Ábel & Dec. 2000 \\
\hline $\begin{array}{l}\text { No. } 355 \text { Optimal Speed of Transition: Micro Evidence from the Czech } \\
\text { Republic }\end{array}$ & $\begin{array}{l}\text { Stepan Jurajda and Katherine } \\
\text { Terrell }\end{array}$ & Dec. 2000 \\
\hline No. 354 Political Instability and Growth in Dictatorships & $\begin{array}{l}\text { Jody Overland, Kenneth L. } \\
\text { Simons and Michael Spagat }\end{array}$ & Nov. 2000 \\
\hline No. 353 Disintegration and Trade & Jarko Fidrmuc and Jan Fidrmuc & Nov. 2000 \\
\hline $\begin{array}{l}\text { No. } 352 \text { Social Capital and Entrepreneurial Performance in Russia: A } \\
\text { Panel Study }\end{array}$ & Bat Batjargal & Dec. 2000 \\
\hline $\begin{array}{l}\text { No. 351 Entrepreneurial Versatility, Resources and Firm Performance in } \\
\text { Russia: A Panel Study }\end{array}$ & Bat Batjargal & Dec. 2000 \\
\hline $\begin{array}{l}\text { No. } 350 \text { The Dynamics of Entrepreneurial Networks in a Transitional } \\
\text { Economy: The Case of Russia }\end{array}$ & Bat Batjargal & Dec. 2000 \\
\hline $\begin{array}{l}\text { No. } 349 \text { R\&D and Technology Spillovers via FDI: Innovation and } \\
\text { Absorptive Capacity }\end{array}$ & Yuko Kinoshita & Nov. 2000 \\
\hline $\begin{array}{l}\text { No. } 348 \text { Microeconomic aspects of Economic Growth in Eastern } \\
\text { Europe and the Former Soviet Union, 1950-2000 }\end{array}$ & Sergei Guriev and Barry W. Ickes & Nov. 2000 \\
\hline $\begin{array}{l}\text { No. } 347 \text { Effective versus Statutory Taxation: Measuring Effective Tax } \\
\text { Administration in Transition Economies }\end{array}$ & $\begin{array}{l}\text { Mark E. Schaffer and Gerard } \\
\text { Turley }\end{array}$ & Nov. 2000 \\
\hline $\begin{array}{l}\text { No. } 346 \text { Objectives and Constraints of Entrepreneurs: Evidence from } \\
\text { Small and Medium Size Enterprises in Russia and Bulgaria }\end{array}$ & $\begin{array}{l}\text { Francesca Pissarides, Miroslav } \\
\text { Singer and Jan Svejnar }\end{array}$ & Oct. 2000 \\
\hline No. 345 Corruption and Anticorruption in the Czech Republic & $\begin{array}{l}\text { Lubomír Lízal and Evžen } \\
\text { Kočenda }\end{array}$ & Oct. 2000 \\
\hline
\end{tabular}




\begin{tabular}{|c|c|c|}
\hline No. 344 The Effects of Direct Foreign Investment on Domestic Firms & Jozef Konings & Oct. 2000 \\
\hline No. 343 On the Identification of Relative Wage Rigidity Dynamics & Patrick A. Puhani & Oct. 2000 \\
\hline $\begin{array}{l}\text { No. } 342 \text { The Determinants of Foreign Direct Investment in Transition } \\
\text { Economies }\end{array}$ & Alan A. Bevan and Saul Estrin & Oct. 2000 \\
\hline No. 341 The Global Spread of Stock Exchanges, 1980-1998 & Klaus Weber and Gerald F. Davis & Nov. 2000 \\
\hline $\begin{array}{l}\text { No. } 340 \text { The Costs and Benefits of Euro-isation in Central-Eastern } \\
\text { Europe Before or Instead of EMU Membership }\end{array}$ & D. Mario Nuti & Oct. 2000 \\
\hline No. 339 Debt Overhang and Barter in Russia & $\begin{array}{l}\text { Sergei Guriev, Igor Makarov and } \\
\text { Mathilde Maurel }\end{array}$ & Sept. 2000 \\
\hline $\begin{array}{l}\text { No. } 338 \text { Firm Performance and the Political Economy of Corporate } \\
\text { Governance: Survey Evidence for Bulgaria, Hungary, Slovakia and } \\
\text { Slovenia }\end{array}$ & $\begin{array}{l}\text { Patrick Paul Walsh and Ciara } \\
\text { Whela }\end{array}$ & July 2000 \\
\hline No. 337 Investment and Instability & $\begin{array}{l}\text { Nauro F. Campos and Jeffrey B. } \\
\text { Nugent }\end{array}$ & May 2000 \\
\hline $\begin{array}{l}\text { No. } 336 \text { The Evolution of the Insurance Sector in Central and } \\
\text { Eastern Europe and the former Soviet Union }\end{array}$ & Robert B.K. Pye & Aug. 2000 \\
\hline $\begin{array}{l}\text { No. } 335 \text { Institutional Technology and the Chains of Trust: Capital } \\
\text { Markets and Privatization in Russia and the Czech Republic }\end{array}$ & Bruce Kogut and Andrew Spicer & Aug. 2000 \\
\hline No. 334 The Evolution of Market Integration in Russia & $\begin{array}{l}\text { Daniel Berkowitz and David N. } \\
\text { DeJong }\end{array}$ & Aug. 2000 \\
\hline No. 333 Efficiency and Market Share in Hungarian Corporate Sector & László Halpern and Gábor Körösi & July 2000 \\
\hline No. 332 Search-Money-and-Barter Models of Financial Stabilization & $\begin{array}{l}\text { S.I. Boyarchenko and S.Z. } \\
\text { Levendorskii }\end{array}$ & July 2000 \\
\hline $\begin{array}{l}\text { No. } 331 \text { Worker Training in a Restructuring Economy: Evidence from } \\
\text { the Russian Transition }\end{array}$ & $\begin{array}{l}\text { erger, John S. Earle } \\
\text { Z. Sabirianova }\end{array}$ & Aug. 2000 \\
\hline $\begin{array}{l}\text { No. } 330 \text { Economic Development in Palanpur 1957-1993: A Sort of } \\
\text { Growth }\end{array}$ & Peter Lanjouw & Aug. 2000 \\
\hline $\begin{array}{l}\text { No. } 329 \text { Trust, Organizational Controls, Knowledge Acquisition from } \\
\text { the Foreign Parents, and Performance in Vietnamese International Joint } \\
\text { Ventures }\end{array}$ & $\begin{array}{l}\text { Marjorie A. Lyles, Le Dang } \\
\text { Doanh, and Jeffrey Q. Barden }\end{array}$ & June 2000 \\
\hline $\begin{array}{l}\text { No. } 328 \text { Comparative Advertising in the Global Marketplace: The } \\
\text { Effects of Cultural Orientation on Communication }\end{array}$ & $\begin{array}{l}\text { Zeynep Gürhan-Canli and } \\
\text { Durairaj Maheswaran }\end{array}$ & Aug. 2000 \\
\hline No. 327 Post Privatization Enterprise Restructuring & Morris Bornstein & July 2000 \\
\hline No. 326 Who is Afraid of Political Instability? & $\begin{array}{l}\text { Nauro F. Campos and Jeffrey B. } \\
\text { Nugent }\end{array}$ & July 2000 \\
\hline No. 325 Business Groups, the Financial Market and Modernization & Raja Kali & June 2000 \\
\hline $\begin{array}{l}\text { No. } 324 \text { Restructuring with What Success? A Case Study of Russian } \\
\text { Firms }\end{array}$ & Susan Linz & July 2000 \\
\hline $\begin{array}{l}\text { No. } 323 \text { Priorities and Sequencing in Privatization: Theory and } \\
\text { Evidence from the Czech Republic }\end{array}$ & $\begin{array}{l}\text { Nandini Gupta, John C. Ham and } \\
\text { Jan Svejnar }\end{array}$ & May 2000 \\
\hline $\begin{array}{l}\text { No. } 322 \text { Liquidity, Volatility, and Equity Trading Costs Across } \\
\text { Countries and Over Time }\end{array}$ & $\begin{array}{l}\text { Ian Domowitz, Jack Glen and } \\
\text { Ananth Madhavan }\end{array}$ & Mar. 2000 \\
\hline $\begin{array}{l}\text { No. } 321 \text { Equilibrium Wage Arrears: A Theoretical and Empirical } \\
\text { Analysis of Institutional Lock-In }\end{array}$ & $\begin{array}{l}\text { John S. Earle and Klara Z. } \\
\text { Sabirianova }\end{array}$ & Oct. 2000 \\
\hline No. 320 Rethinking Marketing Programs for Emerging Markets & $\begin{array}{l}\text { Niraj Dawar and Amitava } \\
\text { Chattopadhyay }\end{array}$ & June 2000 \\
\hline $\begin{array}{l}\text { No. } 319 \text { Public Finance and Low Equilibria in Transition Economies: } \\
\text { the Role of Institutions }\end{array}$ & $\begin{array}{l}\text { Daniel Daianu and Radu } \\
\text { Vranceanu }\end{array}$ & June 2000 \\
\hline $\begin{array}{l}\text { No. } 318 \text { Some Econometric Evidence on the Effectiveness of Active } \\
\text { Labour Market Programmes in East Germany }\end{array}$ & $\begin{array}{l}\text { Martin Eichler and Michael } \\
\text { Lechner }\end{array}$ & June 2000 \\
\hline No. 317 A Model of Russia's "Virtual Economy" & R.E Ericson and B.W Ickes & May 2000 \\
\hline $\begin{array}{l}\text { No. } 316 \text { Financial Institutions, Financial Contagion, and Financial } \\
\text { Crises }\end{array}$ & $\begin{array}{l}\text { Haizhou Huang and Chenggang } \\
\mathrm{Xu}\end{array}$ & Mar. 2000 \\
\hline $\begin{array}{l}\text { No. } 315 \text { Privatization versus Regulation in Developing Economies: The } \\
\text { Case of West African Banks }\end{array}$ & $\begin{array}{l}\text { Jean Paul Azam, Bruno Biais, and } \\
\text { Magueye Dia }\end{array}$ & Feb. 2000 \\
\hline
\end{tabular}




\begin{tabular}{|c|c|c|}
\hline $\begin{array}{l}\text { No. } 314 \text { Is Life More Risky in the Open? Household Risk-Coping and } \\
\text { the Opening of China's Labor Markets }\end{array}$ & John Giles & Apr. 2000 \\
\hline $\begin{array}{l}\text { No. } 313 \text { Networks, Migration and Investment: Insiders and Outsiders in } \\
\text { Tirupur's Production Cluster }\end{array}$ & $\begin{array}{l}\text { Abhijit Banerjee and Kaivan } \\
\text { Munshi }\end{array}$ & Mar. 2000 \\
\hline $\begin{array}{l}\text { No. } 312 \text { Computational Analysis of the Impact on India of the Uruguay } \\
\text { Round and the Forthcoming WTO Trade Negotiations }\end{array}$ & $\begin{array}{l}\text { Rajesh Chadha, Drusilla K. } \\
\text { Brown, Alan V. Deardorff and } \\
\text { Robert M. Stern }\end{array}$ & Mar. 2000 \\
\hline No. 311 Subsidized Jobs for Unemployed Workers in Slovakia & Jan. C. van Ours & May 2000 \\
\hline No. 310 Determinants of Managerial Pay in the Czech Republic & $\begin{array}{l}\text { Tor Eriksson, Jaromir Gottvald } \\
\text { and Pavel Mrazek }\end{array}$ & May 2000 \\
\hline $\begin{array}{l}\text { No. } 309 \text { The Great Human Capital Reallocation: An Empirical Analysis } \\
\text { of Occupational Mobility in Transitional Russia }\end{array}$ & Klara Z. Sabirianova & Oct. 2000 \\
\hline No. 308 Economic Development, Legality, and the Transplant Effect & $\begin{array}{l}\text { Daniel Berkowitz, Katharina } \\
\text { Pistor, and Jean-Francois Richard }\end{array}$ & Feb. 2000 \\
\hline $\begin{array}{l}\text { No. } 307 \text { Community Participation, Teacher Effort, and Educational } \\
\text { Outcome: The Case of El Salvador's EDUCO Program }\end{array}$ & Yasuyuki Sawada & Nov. 1999 \\
\hline No. 306 Gender Wage Gap and Segregation in Late Transition & Stepan Jurajda & May 2000 \\
\hline $\begin{array}{l}\text { No. } 305 \text { The Gender Pay Gap in the Transition from Communism: } \\
\text { Some Empirical Evidence }\end{array}$ & Andrew Newell and Barry Reilly & May 2000 \\
\hline No. 304 Post-Unification Wage Growth in East Germany & Jennifer Hunt & Nov. 1998 \\
\hline $\begin{array}{l}\text { No. } 303 \text { How Does Privatization Affect Workers? The Case of the } \\
\text { Russian Mass Privatization Program }\end{array}$ & Elizabeth Brainerd & May 2000 \\
\hline $\begin{array}{l}\text { No. } 302 \text { Liability for Past Environmental Contamination and } \\
\text { Privatization }\end{array}$ & Dietrich Earnhart & Mar. 2000 \\
\hline No. 301 Varieties, Jobs and EU Enlargement & $\begin{array}{l}\text { Tito Boeri and Joaquim Oliveira } \\
\text { Martins }\end{array}$ & May 2000 \\
\hline No. 300 Employer Size Effec & Todd Idson & Apr. 2000 \\
\hline $\begin{array}{l}\text { No. } 299 \text { Information Complements, Substitutes, and Strategic Product } \\
\text { Design }\end{array}$ & $\begin{array}{l}\text { Geoffrey G. Parker and Marshall } \\
\text { W. Van Alstyne }\end{array}$ & Mar. 2000 \\
\hline $\begin{array}{l}\text { No. } 298 \text { Markets, Human Capital, and Inequality: Evidence from Rural } \\
\text { China }\end{array}$ & $\begin{array}{l}\text { Dwayne Benjamin, Loren Brandt, } \\
\text { Paul Glewwe, and Li Guo }\end{array}$ & May 2000 \\
\hline No. 297 Corporate Governance in the Asian Financial Crisis & $\begin{array}{l}\text { Simon Johnson, Peter Boone, } \\
\text { Alasdair Breach, and Eric } \\
\text { Friedman }\end{array}$ & Nov. 1999 \\
\hline No. 296 Competition and Firm Performance: Lessons from Russia & J. David Brown and John S. Earle & Mar. 2000 \\
\hline No. 295 Wage Determination in Russia: An Econometric Investigation & $\begin{array}{l}\text { Peter J. Luke and Mark E. } \\
\text { Schaffer }\end{array}$ & Mar. 2000 \\
\hline $\begin{array}{l}\text { No. } 294 \text { Can Banks Promote Enterprise Restructuring?: Evidence From } \\
\text { a Polish Bank's Experience }\end{array}$ & John P. Bonin and Bozena Leven & Mar. 2000 \\
\hline No. 293 Why do Governments Sell Privatised Companies Abroad? & $\begin{array}{l}\text { Bernardo Bortolotti, Marcella } \\
\text { Fantini and Carlo Scarpa }\end{array}$ & Mar. 2000 \\
\hline $\begin{array}{l}\text { No. } 292 \text { Going Public in Poland: Case-by-Case Privatizations, Mass } \\
\text { Privatization and Private Sector Initial Public Offerings }\end{array}$ & Wolfgang Aussenegg & Dec. 1999 \\
\hline $\begin{array}{l}\text { No. 291a Institutional Technology and the Chains of Trust: Capital } \\
\text { Markets and Privatization in Russia and the Czech Republic }\end{array}$ & Bruce Kogut and Andrew Spicer & Feb. 2001 \\
\hline $\begin{array}{l}\text { No. } 291 \text { Institutional Technology and the Chains of Trust: Capital } \\
\text { Markets and Privatization in Russia and the Czech Republic }\end{array}$ & Bruce Kogut and Andrew Spicer & Mar. 1999 \\
\hline No. 290 Banking Crises and Bank Rescues: The Effect of Reputation & Jenny Corbett and Janet Mitchell & Jan. 2000 \\
\hline $\begin{array}{l}\text { No. } 289 \text { Do Active Labor Market Policies Help Unemployed Workers to } \\
\text { Find and Keep Regular Jobs? }\end{array}$ & Jan C. van Ours & Feb. 2000 \\
\hline No. 288 Consumption Patterns of the New Elite in Zimbabwe & Russell Belk & Feb. 2000 \\
\hline $\begin{array}{l}\text { No. } 287 \text { Barter in Transition Economies: Competing Explanations } \\
\text { Confront Ukranian Data }\end{array}$ & $\begin{array}{l}\text { Dalia Marin, Daniel Kaufmann } \\
\text { and Bogdan Gorochowskij }\end{array}$ & Jan. 2000 \\
\hline $\begin{array}{l}\text { No. } 286 \text { The Quest for Pension Reform: Poland's Security through } \\
\text { Diversity }\end{array}$ & $\begin{array}{l}\text { Marek Góra and Michael } \\
\text { Rutkowski }\end{array}$ & Jan. 2000 \\
\hline
\end{tabular}


The entire Working Paper Series is available at: www.wdi.bus.umich.edu

\begin{tabular}{|c|c|c|}
\hline No. 285 Disorganization and Financial Collapse & $\begin{array}{l}\text { Dalia Marin and Monika } \\
\text { Schnitzer }\end{array}$ & Oct. 1999 \\
\hline No. 284 Coordinating Changes in M-form and U-form Organizations & $\begin{array}{l}\text { Yingyi Qian, Gérard Roland and } \\
\text { Chenggang Xu }\end{array}$ & May 1999 \\
\hline $\begin{array}{l}\text { No. } 283 \text { Why Russian Workers Do Not Move: Attachment of Workers } \\
\text { Through In-Kind Payments }\end{array}$ & Guido Friebel and Sergei Guriev & Oct. 1999 \\
\hline No. 282 Lessons From Fiascos in Russian Corporate Governance & $\begin{array}{l}\text { Merritt B. Fox and Michael A. } \\
\text { Heller }\end{array}$ & Oct. 1999 \\
\hline $\begin{array}{l}\text { No. } 281 \text { Income Distribution and Price Controls: Targeting a Social } \\
\text { Safety Net During Economic Transition }\end{array}$ & $\begin{array}{l}\text { Michael Alexeev and James } \\
\text { Leitzel }\end{array}$ & Mar. 1999 \\
\hline $\begin{array}{l}\text { No. 280: Starting Positions, Reform Speed, and Economic Outcomes in } \\
\text { Transitioning Economies }\end{array}$ & William Hallagan and Zhang Jun & Jan. 2000 \\
\hline No. 279: The Value of Prominent Directors & $\begin{array}{l}\text { Yoshiro Miwa \& J. Mark } \\
\text { Ramseyer }\end{array}$ & Oct. 1999 \\
\hline No. 278: The System Paradigm & János Kornai & Apr. 1998 \\
\hline $\begin{array}{l}\text { No. 277: The Developmental Consequences of Foreign Direct } \\
\text { Investment in the Transition from Socialism to Capitalism: The } \\
\text { Performance of Foreign Owned Firms in Hungary }\end{array}$ & Lawrence Peter King & Sept. 1999 \\
\hline $\begin{array}{l}\text { No. 276: Stability and Disorder: An Evolutionary Analysis of Russia's } \\
\text { Virtual Economy }\end{array}$ & $\begin{array}{l}\text { Clifford Gaddy and Barry W. } \\
\text { Ickes }\end{array}$ & Nov. 1999 \\
\hline $\begin{array}{l}\text { No. 275: Limiting Government Predation Through Anonymous } \\
\text { Banking: A Theory with Evidence from China. }\end{array}$ & $\begin{array}{l}\text { Chong-En Bai, David D. Li, } \\
\text { Yingyi Qian and Yijiang Wang }\end{array}$ & July 1999 \\
\hline No. 274: Transition with Labour Supply & Tito Boeri & Dec. 1999 \\
\hline $\begin{array}{l}\text { No. 273: Sectoral Restructuring and Labor Mobility: A Comparative } \\
\text { Look at the Czech Republic }\end{array}$ & Vit Sorm and Katherine Terrell & Nov. 1999 \\
\hline $\begin{array}{l}\text { No. 272: Published in: Journal of Comparative Economics "Returns to } \\
\text { Human Capital Under the Communist Wage Grid and During the } \\
\text { Transition to a Market Economy" Vol. 27, pp. 33-60 1999. }\end{array}$ & $\begin{array}{l}\text { Daniel Munich, Jan Svejnar and } \\
\text { Katherine Terrell }\end{array}$ & Oct. 1999 \\
\hline $\begin{array}{l}\text { No. 271: Barter in Russia: Liquidity Shortage Versus Lack of } \\
\text { Restructuring }\end{array}$ & $\begin{array}{l}\text { Sophie Brana and Mathilde } \\
\text { Maurel }\end{array}$ & June 1999 \\
\hline $\begin{array}{l}\text { No. 270: Tests for Efficient Financial Intermediation with Application to } \\
\text { China }\end{array}$ & Albert Park and Kaja Sehrt & Mar. 1999 \\
\hline $\begin{array}{l}\text { No. 269a: Russian Privatization and Corporate Governance: What Went } \\
\text { Wrong? }\end{array}$ & $\begin{array}{l}\text { Bernard Black, Reinier Kraakman } \\
\text { and Anna Tarassova }\end{array}$ & May 2000 \\
\hline $\begin{array}{l}\text { No. 269: Russian Privatization and Corporate Governance: What Went } \\
\text { Wrong? }\end{array}$ & $\begin{array}{l}\text { Bernard Black, Reinier Kraakman } \\
\text { and Anna Tarassova }\end{array}$ & Sept. 1999 \\
\hline No. 268: Are Russians Really Ready for Capitalism? & Susan Linz & Sept. 1999 \\
\hline No. 267: Do Stock Markets Promote Economic Growth? & $\begin{array}{l}\text { Randall K. Filer, Jan Hanousek } \\
\text { and Nauro Campos }\end{array}$ & Sept. 1999 \\
\hline $\begin{array}{l}\text { No. 266: Objectivity, Proximity and Adaptability in Corporate } \\
\text { Governance }\end{array}$ & $\begin{array}{l}\text { Arnoud W.A Boot and Jonathan } \\
\text { R. Macey }\end{array}$ & Sept. 1999 \\
\hline $\begin{array}{l}\text { No. 265: When the Future is not What it Used to Be: Lessons from the } \\
\text { Western European Experience to Forecasting Education and Training in } \\
\text { Transitional Economies }\end{array}$ & $\begin{array}{l}\text { Nauro F. Campos, Gerard } \\
\text { Hughes, Stepan Jurajda, and } \\
\text { Daniel Munich }\end{array}$ & Sept. 1999 \\
\hline $\begin{array}{l}\text { No. 264: The Institutional Foundation of Foreign-Invested Enterprises } \\
\text { (FIEs) in China }\end{array}$ & Yasheng Huang & Sept. 1999 \\
\hline $\begin{array}{l}\text { No. 263: The Changing Corporate Governance Paradigm: Implications } \\
\text { for Transition and Developing Countries }\end{array}$ & $\begin{array}{l}\text { Erik Berglof and Ernst-Ludwig } \\
\text { von Thadden }\end{array}$ & June 1999 \\
\hline No. 262: Law Enforcement and Transition & $\begin{array}{l}\text { Gerard Roland and Thierry } \\
\text { Verdier }\end{array}$ & May 1999 \\
\hline $\begin{array}{l}\text { No. 261: Soft Budget Constraints, Pecuniary Externality, and the Dual } \\
\text { Track System }\end{array}$ & Jiahua Che & June 2000 \\
\hline $\begin{array}{l}\text { No. 260: Missing Market in Labor Quality: The Role of Quality Markets } \\
\text { in Transition }\end{array}$ & Gary H. Jefferson & July 1999 \\
\hline $\begin{array}{l}\text { No. 259: Do Corporate Global Environmental Standards in Emerging } \\
\text { Markets Create or Destroy Market Value }\end{array}$ & $\begin{array}{l}\text { Glen Dowell, Stuart Hart and } \\
\text { Bernard Yeung }\end{array}$ & June 1999 \\
\hline
\end{tabular}

